\title{
Trends in international migration and remittance flows: Case of Bangladesh
}

\author{
K. S. Farid, L. Mozumdar, M. S. Kabir and K. B. Hossain ${ }^{1}$ \\ Department of Rural Sociology, Bangladesh Agricultural University, Mymensingh-2202, Bangladesh and ${ }^{1}$ Department \\ of Statistics, University of Chittagong, Bangladesh
}

\begin{abstract}
International migration from Bangladesh has become a defining characteristic of the country. Especially since 1980s, large scale labour migration has become a common phenomenon of Bangladesh. This paper examines the various issues of international migration and remittance flows of Bangladesh on the basis of the secondary data generated from various reports of government and non-government organizations and of various publications of home and abroad. With a few exceptions, manpower export has been showing increasing trend year by year. Most of the expatriates, who are largely unskilled, are working in the Middle East countries and in the UK and the USA. Like overseas employment, remittances flow has been increasing every year with its increased share in GDP and export earnings. Major share of total remittances come from the Middle East countries. But individually the position of the USA is just behind Saudi Arabia over the last few years. Finally it can be concluded that proper attention should be given on overseas migration in order to keep the unemployment rate within tolerable level and to increase the amount of remittances which is an important source of foreign exchange.
\end{abstract}

Keywords: International migration, Remittance, Expatriate, Employment, Increased share in GDP

\section{Introduction}

Human migration is the movement of people from one place to another for purposes of permanent or temporary residence and/or employment. In general, human migration has occurred throughout history and began with the movements of the first human groups out of their origins in East Africa (Tigno, 2006). Migration is complex, migration flows are dynamic and constantly changing, the many different types and contexts of migration make it difficult to make satisfying theories and generalizations (Zeitlyn, 2006). Migration in general may be in the form of internal and international. International migration in general has become an extensive global phenomenon. Within the last decade at least, the number of people crossing borders has increased by around six million annually. This rate is even faster than the growth rate of the world's population. The total number of persons residing outside their country of birth has reached to almost 175 million by 2000 , which is roughly equivalent to three percent of the world's total population. Indeed, if international migrants were considered together they would account for the world's fifth most populous country (ILO, 2004). Migration, however, has long been an important livelihood strategy for the people involved in the process of migration, especially for the migrant people of developing and least developed countries (Siddiqui, 2003). Overseas migration not only produces large inflows of valuable remittances but also offers an outlet for frustrated unemployed workers who might otherwise present serious domestic problems. It is also important in order to reduce unemployment at home and accumulate valuable foreign exchange to stimulate economic growth (Hadi, 1999).

Bangladesh is a hugely labour surplus country and consequently participates in the supply side of the global labour market (Refugee and Migratory Movement Research Unit, 2008). The country has a long history of migration and it is one of the major labour-exporting countries in the world. Each year a large number of people of this country voluntarily migrate overseas for both long- and short-term employment (Siddiqui, 2005). Despite country's long history of migration, increase in oil price in 1970s opened up vast scope for Bangladeshi migrants in the Middle East which was later on expanded to the newly industrialized countries of South East Asia (Siddiqui, 2003). Labour migration from Bangladesh was geared furthermore for the government of Bangladesh promoting international labour migration as part of an overall development plan since 1976 (Refugee and Migratory Movement Research Unit, 2007). Moreover, the country became major source country of migrant workers during the 1980s (Mannan, 2001). With the passage of time international migration became part of the economic, social and political fabric of the country. Remittances flow is one of most visible attributes of international migration. It is important to assess the stock of international migrants who were migrated from Bangladesh and the flows of remittances to Bangladesh which are the basic objectives of the present study. The general objective of this study is to increase the literature and understanding on the international migration and remittances issues. The specific objectives of this paper are -

i. $\quad$ to investigate the shifting flows of migrations from Bangladesh, and

ii. to find out the remittance flows from overseas migrants to Bangladesh. 


\section{Materials and Methods}

This paper is solely based on secondary data which were collected by surveying published and unpublished reports of various government and non-government organizations such as Bangladesh Economic Review (BER), websites of Ministry of Expatriate's Welfare and Overseas Employment, Bangladesh Bank, Bureau of Manpower Employment and Training (BMET) and Refugee and Migratory Movements Research Unit (RMMRU). An extensive review of literature was done in order to gain familiarity with the study. Tabular and graphical analyses were done with the collected data in order to achieve the objectives of the study.

\section{Trends in Migration Flows from Bangladesh}

Overseas employment contributes significantly to the economic development of the country. From the inception of manpower export in 1976 to 2008, manpower having strength of about 6.57 million has been exported. Including first seven months of 2009, total number of manpower exported to foreign countries was about 6.8 million (BMET, 2009). Only in 2008 about 0.88 million people have migrated for foreign employment. With a few exceptions, manpower export has been increasing every year. Table 1 shows the trends in oversees employment from the period of 1976 to 2007 by using various categories of fouryear total. Only 69116 Bangladeshis had gone abroad for employment during 1976-1979 and during 2004-2007, this figure has reached to about 1.74 million. During 1992-1995, manpower exports accounted for 0.81 million, which is about 52 percent higher than the period of 1988-1991. There was slight decrease in population migration during 2000-2003 and the rate of decrease was 8.95 percent than the previous period (1996-1999). In 1999, altogether 268182 persons migrated; the figure dropped to 222686 in 2000 and further to 188965 in 2001 (BER, 2008). The probable reasons for this may be multiple. One reason may be due to the stiff competition from new labour-exporting countries like Nepal, Vietnam and Cambodia, which have recently entered the international labour market and supply cheaper labour. Another reason may have been the rise in unemployment in some Arab countries, which has spawned policy decisions to indigenise the labour force. In doing so the Arab countries increased the cost of formal emigration, which has decreased the number of formal migrants. A large number of Bangladeshis are also believed to have gone to the Middle East through irregular channels (Siddiqui, 2003). Moreover, there is a sharp decrease in the manpower export in the first seven months of 2009 which is largely due to the ongoing world-wide economic crisis of last year. From January to July 2008, a total of 572098 manpower was exported abroad. But this figure dropped to only 288903 during the same period of 2009, which is about half of the last year (Bangladesh Bank, 2009).

Table 1. Trends in overseas employment

\begin{tabular}{|l|c|c|}
\hline Year & No. of expatriates & Percentage change \\
\hline $1976-1979$ & 69116 & - \\
\hline $1980-1983$ & 207842 & 200.71 \\
\hline $1984-1987$ & 277083 & 33.31 \\
\hline $1988-1991$ & 420790 & 51.86 \\
\hline $1992-1995$ & 806501 & 91.66 \\
\hline $1996-1999$ & 978640 & 21.34 \\
\hline $2000-2003$ & 891097 & -8.95 \\
\hline $2004-2007$ & 1739785 & 95.24 \\
\hline
\end{tabular}

Source: BMET, 2008

Female migration from Bangladesh is an uncommon phenomenon. During the period of 1991-1995, only 9308 female migrated from Bangladesh which constituted only 0.98 per cent of the total migrants. The percentage of female migrants dropped to 0.42 per cent during the period of 1996-2000 (Siddiqui, 2005). However, Table 2 shows the trend in female migration from Bangladesh during the period of 2001-2007 which depicts that Bangladeshi migrant workers are predominantly men. Female migrants constitute only 66076, among a total of 2408196 migrants from 2001-2007, which is less than 3 per cent of the total migrants of Bangladesh. 
Table 2. Trends in female migration from 1991-2007

\begin{tabular}{|c|c|c|c|}
\hline \multirow{2}{*}{ Year } & \multirow{2}{*}{ Number of migrants } & \multicolumn{2}{|c|}{ Women migrants } \\
\cline { 3 - 4 } & & Number & \% of total migrants \\
\hline 2001 & 188965 & 659 & 0.35 \\
\hline 2002 & 225256 & 1217 & 0.54 \\
\hline 2003 & 254190 & 2400 & 0.94 \\
\hline 2004 & 272958 & 11200 & 4.10 \\
\hline 2005 & 252702 & 13600 & 5.38 \\
\hline 2006 & 381516 & 18100 & 4.74 \\
\hline 2007 & 832609 & 18900 & 2.27 \\
\hline Total & 2408196 & 66076 & 2.74 \\
\hline
\end{tabular}

Source: Bangladesh Economic Review, 2008

This low rate is due to the imposition of ban in 1981 on the migration of all categories of female workers other than professional which was later on replaced by the imposition of restrictions on unskilled and semi-skilled female migration in 1987. A ban was again imposed in 1997 on all categories of women workers, including professional and this was changed to restriction from which professional were excluded. Since 2003, the restrictions apply only to unskilled and semi-skilled women workers under the age of 35, who are not allowed to migrate on their own (Siddiqui, 2005). But this restriction increases the outflow of female migrants from Bangladesh through unofficial channels. The number of female migrants, therefore, might be 10 to 50 times more than the official figures (Siddiqui, 2001).

It has been observed that most of the expatriates are working in Saudi Arabia, the U.A.E., Malaysia, the U.K., Kuwait, the U.S.A., Oman and Singapore. Besides, new employment opportunities for Bangladeshi workers have also been created in Bahrain, Qatar, Jordan, South Korea, Brunei, Mauritius, Italy and other countries. During 1976 to October 2008, Saudi Arabia ranked for first and foremost destination for Bangladeshi migrants accounted for about 42 percent of total manpower export (Table 3).

Table 3. Number of overseas migrants by major receiving countries (1976 to October 2008)

\begin{tabular}{|l|c|c|}
\hline Country & Total migrants & Percent \\
\hline Saudi Arabia & 2554879 & 41.52 \\
\hline UAE & 1266287 & 20.58 \\
\hline Malaysia & 667383 & 10.85 \\
\hline Kuwait & 479534 & 7.79 \\
\hline Oman & 312741 & 5.08 \\
\hline Singapore & 231870 & 3.77 \\
\hline Bahrain & 160175 & 2.60 \\
\hline Libya & 59360 & 0.96 \\
\hline Jordan & 22912 & 0.37 \\
\hline Italy & 20298 & 0.33 \\
\hline South Korea & 19588 & 0.32 \\
\hline Qatar & 140933 & 2.29 \\
\hline Other countries & 166003 & 2.70 \\
\hline Miscellaneous clearance & 51494 & 0.84 \\
\hline Total & 6153457 & 100.00 \\
\hline
\end{tabular}

Source: BMET, 2009 
The labour market for Bangladeshi migrants, however, is not static. For example, during the 1970s Saudi Arabia, Iraq, Iran and the Libyan Arab Jamahiriya were some of the major destination countries. While Saudi Arabia has remained the top destination, Malaysia and the UAE also became important receivers. Malaysia used to be the second largest employer of Bangladeshi workers. However, since the Asian financial crisis of 1997, the number of Bangladeshi migrants to Malaysia has decreased and the UAE has taken the place (Siddiqui, 2005). By October 2008, the UAE and Malaysia remain as the second and third important destinations of Bangladeshi migrants occupying 20.58 percent and 10.85 percent migrants, respectively. That is, Saudi Arabia alone constitutes more than one-third share of overseas employment. Again Saudi Arabia and the U.A.E., both are the destinations of more than half of the exported manpower of Bangladesh. Other important destinations of Bangladeshi migrants are the U.K., Kuwait, the U.S.A., etc.

Though Malaysia is an important destination of Bangladeshi migrants, Asian financial crisis of 1997 slowed down migration from Bangladesh to Malaysia during 1998-2004. There were only 25957 people migrated to Malaysia during that period which was very much lower than that of people migrated in 1997 accounted for about 0.15 million (BMET, 2009). Fig. 1 shows the trend in migration classified by major destinations from the period from 1976 to 2007.

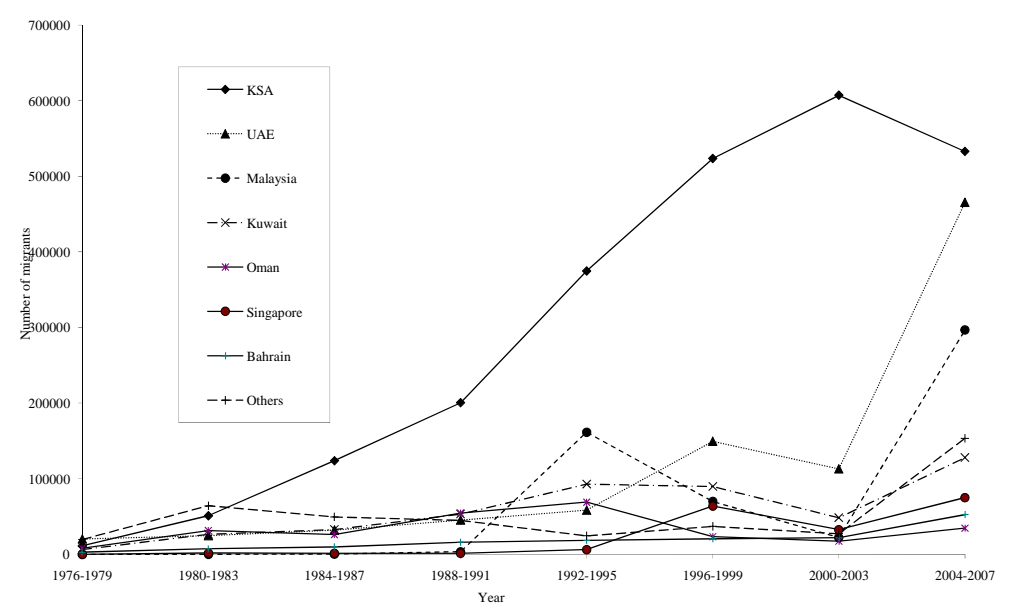

Fig.1. Trend in overseas expatriates classified by major countries

Various categories of Bangladeshis like professionals, skilled, semi-skilled, and unskilled labour force are employed in different countries. Doctors, engineers, teachers and nurses are considered as professional workers, while manufacturing or garment workers, drivers, computer operators and electricians as skilled. Tailors and masons are considered as semi-skilled, and housemaids, agricultural workers, hotel workers and menial workers as unskilled workers. About 6.57 million Bangladeshi workers got overseas employment during 1976 to 2008. Out of them, the highest 50 percent are unskilled worker followed by 31 percent of skilled, 16 percent of semi-skilled and 3 percent of professional (BMET, 2009). Though there are fluctuating trends in the number of professional and semi-skilled workers, except for 2000-2003 period, the number of skilled manpower increased all over the period that is from 1976-1979 to 20042007 and there is a increasing trend of unskilled manpower during the whole period which is shown in Fig. 2. 


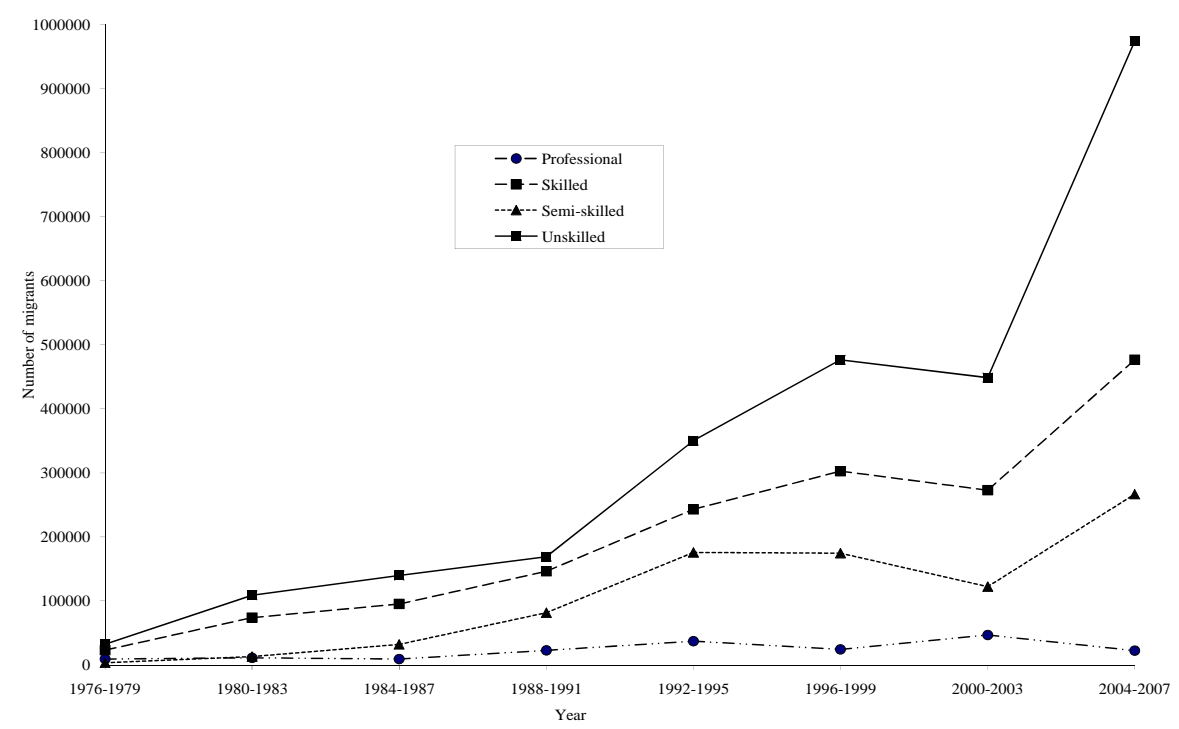

Fig. 2. Trend in overseas migrants classified by skill

\section{Remittance Flows to Bangladesh}

Remittances sent by overseas migrants contribute a lot to the economic development of the country through augmenting foreign exchange reserves and income. Like overseas employment, expatriate workers' remittances flow has been showing increasing trend year by year. Remittances sent by the overseas migrants have increased from US\$23.71 million in 1976 to US\$ 9019.60 million in 2008 (Bangladesh Bank, 2009). During 1976-1979, the amount of remittances from expatriate Bangladeshi workers was only US\$385.46 million which was increased to US\$ 1724.46 million during 1980-1983 reflecting 347.38 percent rise over the previous period. During 2004-2007, remittances stood at US\$ 18049.98 million showing 79.58 percent increase over the previous period i.e., 2000-2003 (Table 4). The continuous augmentation in workers' remittances is mainly due to the increase of skilled manpower export and the creation of facilities to send remittances from abroad.

Table 4. Trends in remittance flows to Bangladesh

\begin{tabular}{|l|c|c|c|c|}
\hline Year & Million US \$ & Percentage change & Crore Tk. & Percentage change \\
\hline $1976-1979$ & 385.46 & - & 593.55 & - \\
\hline $1980-1983$ & 1724.49 & 347.38 & 3859.29 & 615.28 \\
\hline $1984-1987$ & 2323.80 & 34.75 & 6751.89 & 74.95 \\
\hline $1988-1991$ & 3072.58 & 32.22 & 10379.87 & 53.73 \\
\hline $1992-1995$ & 4266.12 & 38.84 & 16968.17 & 63.47 \\
\hline $1996-1999$ & 6286.24 & 47.35 & 28790.42 & 69.67 \\
\hline $2000-2003$ & 10051.40 & 59.90 & 56759.56 & 97.15 \\
\hline $2004-2007$ & 19863.43 & 97.62 & 132696.70 & 133.79 \\
\hline
\end{tabular}

Source: BMET, 2008 
The contribution of remittance to Gross Domestic Products (GDP) has grown from a meagre 1 per cent in 1977-1978 to 5.2 per cent in 1982-1983. But during the 1990s, the ratio hovered around 4 per cent (Siddiqui, 2005). It reached to 5.26 per cent in 2001-2002 and by showing an increasing trend it reached to 10.02 per cent in 2007-2008 (Table 5). The amount of remittances in terms of export earnings has also been increased. In fiscal year 1998-1999, remittances as percent of export stood at 32.04 percent, which has increased to 56.09 percent in 2007-2008. But, if the unofficial flow of remittances is taken into account, its contribution to GDP and export earnings would certainly be much higher.

Table 5. Remittances as percent of GDP and export

\begin{tabular}{|l|c|c|}
\hline Fiscal year & As percent of GDP & As percent of export \\
\hline $1998-1999$ & 3.74 & 32.04 \\
\hline $1999-2000$ & 4.14 & 33.89 \\
\hline $2000-2001$ & 4.01 & 29.10 \\
\hline $2001-2002$ & 5.26 & 41.78 \\
\hline $2002-2003$ & 5.90 & 46.76 \\
\hline $2003-2004$ & 5.98 & 44.35 \\
\hline $2004-2005$ & 6.37 & 44.47 \\
\hline $2005-2006$ & 7.75 & 45.62 \\
\hline $2006-2007$ & 8.83 & 49.09 \\
\hline $2007-2008$ & 10.02 & 56.09 \\
\hline
\end{tabular}

Source: Bangladesh Economic Review, 2008

Major share of total remittances in Bangladesh came from the countries of the Middle East. But individually Saudi Arabia stood at first position. Over the last few years (from 2001-2002) the USA stood the second position. In 2008-2009, the highest amount of remittances came from Saudi Arabia which was US\$ 2121.42 followed by US\$1213.72 from the U.S.A., US\$1209.74 from the U.A.E., US\$ 726.35 from Kuwait, and US\$ 577.89 from the U.K, respectively. It is observed that the remittances from the U.K. grew significantly in the last couple of years and Italy is also becoming a significant contributor of remittance earnings of this country. The amount of remittances earned from Italy was only US\$ 0.41 million in 20002001 which was increased to US\$214.46 million in 2007-2008.

Table 6. Trends in country wise remittances (in million US \$)

\begin{tabular}{|l|c|c|c|c|c|c|}
\hline Country & $1995-1996$ & $2000-2001$ & $2005-2006$ & $2006-2007$ & $2007-2008$ & $2008-200{ }^{*}$ \\
\hline KSA & 498.20 & 919.61 & 1696.96 & 1734.70 & 2324.23 & 2121.42 \\
\hline UAE & 83.70 & 144.28 & 561.44 & 804.84 & 1135.14 & 1209.74 \\
\hline Qatar & 53.28 & 63.44 & 175.64 & 233.17 & 289.79 & 253.23 \\
\hline Oman & 81.71 & 83.66 & 165.25 & 196.47 & 220.64 & 216.21 \\
\hline Bahrain & 30.08 & 44.05 & 67.33 & 79.96 & 138.20 & 121.76 \\
\hline Kuwait & 174.27 & 247.39 & 494.39 & 680.70 & 863.73 & 726.35 \\
\hline USA & 115.36 & 225.62 & 760.69 & 930.33 & 1380.08 & 1213.72 \\
\hline UK & 41.28 & 55.70 & 555.71 & 886.90 & 896.13 & 577.89 \\
\hline Malaysia & 74.43 & 30.60 & 20.82 & 11.84 & 92.44 & 168.60 \\
\hline Singapore & 3.99 & 7.84 & 68.84 & 80.24 & 130.11 & 115.44 \\
\hline Italy & $\mathrm{NA}$ & 0.41 & 78.43 & 149.65 & 214.46 & $\mathrm{NA}$ \\
\hline Others & 60.76 & 59.50 & 160.38 & 189.67 & 229.83 & 309.83 \\
\hline Total & 1217.06 & 1882.10 & 4801.88 & 5978.47 & 7914.78 & 7033.87 \\
\hline
\end{tabular}

Source: Bangladesh Bank, 2009

Note: * Up to March 2009, NA = Not Available

Fig. 3 shows the relationship between the flows of migration and remittances. Total number of overseas migrants show more or less fluctuating trend between the period from 1990 to 2005, which increases sharply in 2006 and 2007. Total amount of remittances sent by the overseas migrants shows an increasing trend during the whole period. However, the rate of increase is very high after 2004. 


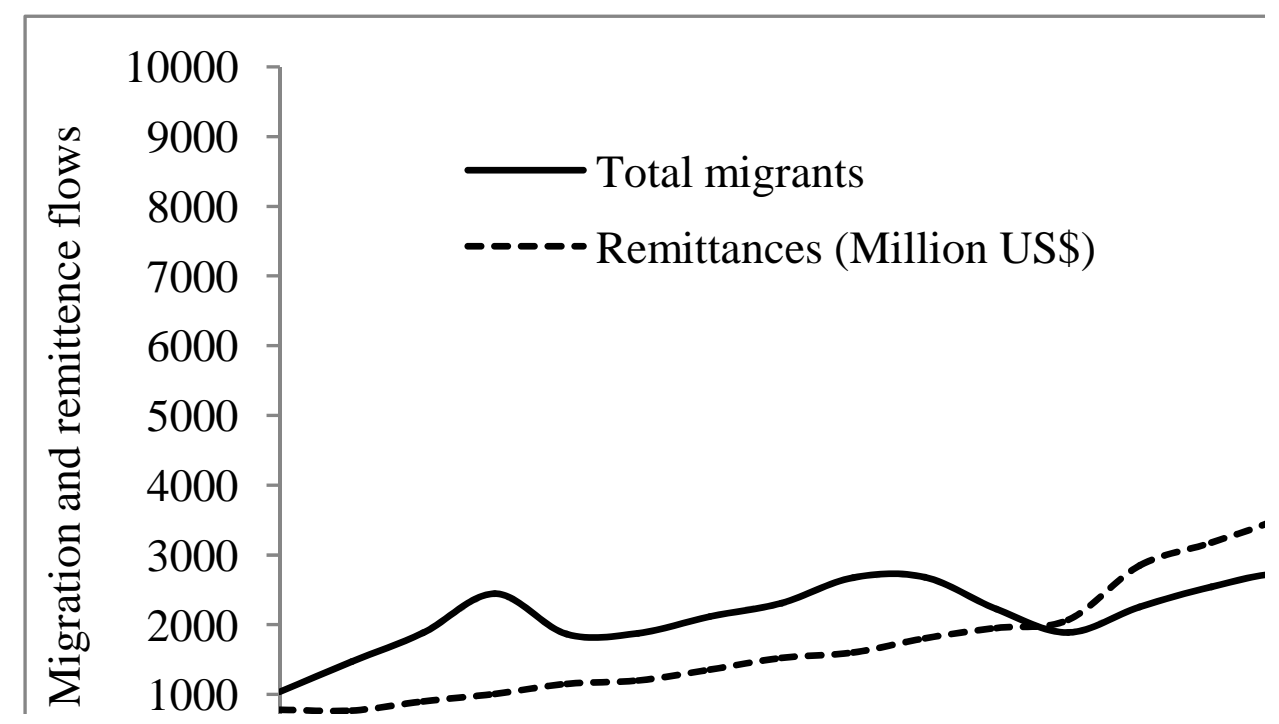

Fig. 3. Relationship between migration and remittances

Fig. 4 shows the annual growth rate of migration and remittances from 1992 to 2008 which is calculated as percentage change with the previous year. Both the growth rates show fluctuating trend over the years, but the rate of fluctuation is very much high for growth rate of migration than that of remittances. In some instances, the annual growth rate of remittances is much less than the growth rate of the total number of migrant workers. In 1992, emigration increased by about 30 per cent over the previous year, whereas remittances grew by about 18 per cent over the same period. For 2007, emigration grew by about 118 per cent compared to the figure for 2006 and remittance flow increased only by about 19 per cent. But in 2008 growth rate of remittance was higher than the growth rate of migration. In 2008, overseas emigration grew at a rate of 5 per cent; on the other hand, remittances increased by 36 per cent during that time (Calculated from Bangladesh Bank data). The main reason for the gap between the number of migrants and remittance flows is that Bangladesh has exported more unskilled and semiskilled migrants, whose wages are rather low compared to those of skilled and professional workers (Siddiqui and Abrar, 2001). Though in some cases growth rate of migration is negative, the growth of remittances always shows positive rate. The highest gap between the two growth rates is prevalent during the year 2007.

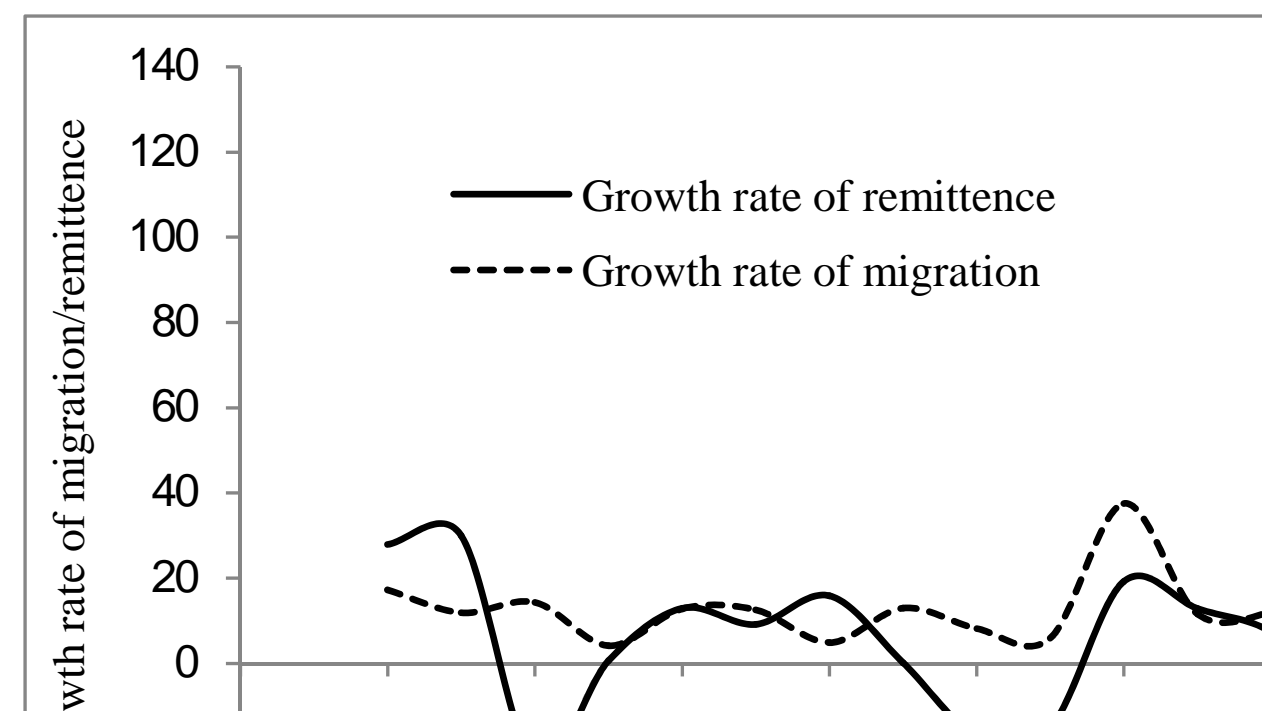

Fig. 4. Growth rate of migration and remittances over the years 


\section{Conclusion}

This paper has attempted to capture different aspects of voluntary migration from Bangladesh on the basis of available secondary information. As Bangladesh is a hugely labour surplus country and as it is not possible for the successive Bangladeshi Government to create employment opportunities for all of its manpower, international migration would the best possible option for these Bangladeshi migrants. Although the Government of Bangladesh is committed to promoting short-term international migration, it does not have any planned programme for accessing the rapidly changing international labour market. So, to reap the benefits of overseas migration, the Government of Bangladesh should give special attention on this issue. Because it is international migration, which would play vital and indispensable role in the national economy of Bangladesh by creating employment opportunities in abroad and increasing the flow of remittances - important but inexpensive source of much needed foreign exchange. However, it can be turned into a major development enhancing process which can reduce poverty and be an important livelihood strategy of the poor Bangladeshi.

\section{Reference}

Bangladesh Bank. 2009. The Central Bank of Bangladesh, Government of the People's Republic of Bangladesh, Dhaka (From http://www.bangladesh-bank.org)

Bangladesh Economic Review. 2008. Economic Advisor Wing, Finance Division, Ministry of Finance, Government of the People's Republic of Bangladesh, Dhaka.

Bangladesh Economic Review. 2009. Economic Advisor Wing, Finance Division, Ministry of Finance, Government of the People's Republic of Bangladesh, Dhaka (accessed from http://www.mof.gov.bd/en/budget/09_10/ber/bn/07.\%20Chapter3\%20_Bangla-9_.pdf)

BMET. 2009. Bureau of Manpower Employment and Training, Government of the Peoples' Republic of Bangladesh, Dhaka. (From http://www.bmet.org.bd)

Hadi, A. 1999. Overseas Migration and the Well-being of Those Left Behind in Rural Communities of Bangladesh. Asia-Pacific Population Journal, 14(1): 43-58.

ILO. 2004. Report VI: Towards a Fair Deal for Migrant Workers in the Global Economy, Sixth Item on the Agenda, International Labour Office, Geneva.

Mannan, M.A. 2001. Bangladeshi Migrants in Saudi Labour Market: An Empirical Analysis, RMMRU, Dhaka.

Refugee and Migratory Movement Research Unit. 2007. The Case for Ratification: 1990 UN Convention on the Protection of Migrant Workers' Rights, Policy Brief 3, RMMRU, Dhaka.

Refugee and Migratory Movement Research Unit. 2008. Migration, Remittances and Development, Policy Brief 4, RMMRU, Dhaka.

Siddiqui, T. 2001. Transcending Boundaries: Labour Migration of Women from Bangladesh, University Press Limited, Dhaka.

Siddiqui, T. and Abrar, C.R. 2001. Migrant Workers' Remittances and Micro-finance Institutions, International Labour Organization (mimeo), Geneva.

Siddiqui, T. 2003. Migration as a Livelihood Strategy of the Poor: The Bangladesh case, Paper presented at the DFID-RMMRU Regional Conference on Migration, Development and Pro-poor Policy Choices in Asia, held in Dhaka, 22-24 June, 2003.

Siddiqui, T. 2005. International Labour Migration from Bangladesh: A descent work perspective. Working Paper No.66, Policy Integration Department, National Policy Group, International Labour Office, Geneva.

Tigno, J.V. 2006. Trans-national Labour Migration: Issues, Trends and Strategies for East Asian Community Building, Paper presented at the International Conference on Across the Border Issues, from 30-31 March, 2006 organized by Academy of East Asian studies, Sungkyunkwan University, Seoul.

Zeitlyn, B. 2006. Migration from Bangladesh to Italy and Spain. Refugee and Migratory Movements Research Unit, Dhaka. 